Thorax (1953), 8, 288.

\title{
THE VALUE OF CYTOLOGICAL EXAMINATION OF THE SPUTUM IN THE DIAGNOSIS OF CARCINOMA OF THE BRONCHUS
}

\author{
BY \\ R. C. JENNINGS AND K. M. SHAW \\ From the London Chest Hospital \\ (RECEIVED FOR PUBLICATION MARCH 9, 1953)
}

There are few conditions occurring within the thoracic cage which cannot be simulated by cancer of the lung, and in about half of the cases investigated the diagnosis remains at best presumptive and at worst no more than speculative. This unsatisfactory situation has stimulated the search for further diagnostic aids and has given rise to increasing interest in the cytological investigation of sputum.

In recent years a positive cytological diagnosis in such cases has been recorded in percentages ranging from 42.8 (Liebow, Lindskog, and Bloomer, 1948) to 84 (Wandall, 1944). Many of these results have been presented as preliminary surveys to assess the accuracy of this method. The examination of sputum for malignant cells was started at this hospital by the late Dr. Roodhouse Gloyne and has been employed for the last 16 years. Initial uncertainty about the accuracy of the method resulted in a limitation of its use, but with increasing clinical confidence in the results the number of sputa examined rose proportionately, and since 1943 it has become a routine examination for all non-tuberculous cases.

Our purpose is to confirm an impression of the great value of this investigation and to encourage its wider use by presenting the results of a series in which the wet-film-methylene-blue staining method was used.

\section{Historical Review}

Walshe (1843) first described particles of malignant tissue coughed up from the respiratory tract. Further contributions, mostly concerned with reports of isolated cases, came from Beale (1860), Hampeln (1887), Bezançon and de Jong (1912), and others. The systematic investigation of the method dates from the work of Dudgeon, Wrigley, Barrett, Patrick, and Bamforth at St. Thomas's Hospital (Dudgeon and Patrick, 1927 ; Dudgeon and Barrett, 1934 ; Dudgeon and Wrigley, 1935 ;
Dudgeon, 1936 ; Barrett, 1938 ; and Bamforth? 1946). These authors showed that exfoliated malignant cells could be found in the sputum in considerable numbers of cases of bronchogenic carcinoma.

Gloyne (1936) gave a detailed account of the ${ }^{\mathbb{D}}$ method of selection and examination of the $\overrightarrow{0}$ sputum. Wandall of Copenhagen (1944) in anw excellent monograph recorded $84 \%$ positive results in 100 proved lung cancers. Since 1948 the cytological method has been investigated mainly in the U.S.A. Notable contributions have come from Woolner and McDonald (1949 and 1950), Farber, 0 Rosenthal, Alston, Benioff, and McGrath (1950) and Watson, Cromwell, Craver, and Papanicolaove (1949). Clerf and Herbut (1950) and McKay, Ware, Atwood, and Harken (1948) have reported excellent results using bronchial aspirates. Table I shows the results obtained by previous authors together with the figures which form the basis of this paper.

\section{EXAMINATION OF SPUTUM}

Two main staining methods have been pre viously described. Dudgeon and Wrigley (1935) used Schaudinn-fixed wet films stained with? Meyer's haemalum and counter-stained with eosin. The Dudgeon technique was used by Gowar (1943) and Wandall (1944).

In America the success of the Papanicolaot stain in the diagnosis of uterine (Papanicolaou, 1942) was followed by its wide use in sputum cytology with excellent results (Papani2 colaou and Cromwell, 1949) and Jackson, Bertolie and Ackerman (1951). The Papanicolaou tech- $-\frac{\Phi}{c}$ nique consists of ether-alcohol fixation and stain :ing with various modifications by compound $\frac{0}{0}$ stains.

Since 1939 a wet-film-methylene-b'ue staining technique as described by Schuster (1947) has been used at this hospital, but glycerine is not incor? 
TABLE I

RESULTS OF REPORTED SERIES OF CYTOLOGICALLY EXAMINED BRONCHOGENIC CARCINOMA

\begin{tabular}{|c|c|c|c|c|}
\hline \multirow{2}{*}{ Author } & \multirow{2}{*}{$\begin{array}{c}\text { No. of } \\
\text { Cases } \\
\text { Investi- } \\
\text { gated }\end{array}$} & \multirow{2}{*}{$\begin{array}{l}\text { No. with } \\
\text { Bronchial } \\
\text { Carcinoma }\end{array}$} & \multicolumn{2}{|c|}{ Cytology Positive } \\
\hline & & & No. & $\%$ \\
\hline $\begin{array}{l}\text { Dudgeon and Wrigley } \\
(1935)\end{array}$ & 58 & 38 & 26 & 68 \\
\hline $\begin{array}{l}\text { Barrett (1937) (these } \\
\text { are Dudgeon's figures } \\
\text { up to that time) }\end{array}$ & & 110 & 68 & $61 \cdot 8$ \\
\hline \begin{tabular}{ll|} 
Gowar (1943) &.. \\
Wandall (1944) &..
\end{tabular} & $\begin{array}{r}93 \\
250\end{array}$ & $\begin{array}{r}65 \\
100\end{array}$ & $\begin{array}{l}36 \\
84\end{array}$ & $\begin{array}{l}64 \cdot 3 \\
84\end{array}$ \\
\hline $\begin{array}{l}\text { Liebow and others } \\
\text { (1948) }\end{array}$ & 112 & 49 & 21 & $42 \cdot 5$ \\
\hline $\begin{array}{c}\text { McKay and others } \\
\text { (1948) }\end{array}$ & 170 & 54 & 40 & 74 \\
\hline $\begin{array}{l}\text { Kjer, T., and others } \\
\text { (1949) }\end{array}$ & 236 & 112 & $\begin{array}{c}46 \\
\text { Definite }\end{array}$ & 41 \\
\hline & & & $\begin{array}{c}\text { tumour cells } \\
30 \\
\text { Suspect or }\end{array}$ & 27 \\
\hline$\underset{(1949)}{\text { Watson }}$ and others & 400 & 236 & $\begin{array}{c}139 \\
\text { Some of these } \\
\text { were bron- }\end{array}$ & 60 \\
\hline $\begin{array}{l}\text { Clerf and Herbut (1950) } \\
\text { All examinations } \\
\text { made on bronchial } \\
\text { aspirates }\end{array}$ & & 285 & $\mid \begin{array}{c}\text { chial aspirates } \\
253\end{array}$ & $88 \cdot 8$ \\
\hline $\begin{array}{l}\text { Farber and others } \\
(1950)\end{array}$ & 1,254 & 197 & 108 & 55 \\
\hline $\begin{array}{l}\text { Perrin and Littlejohn } \\
\text { (1950) }\end{array}$ & 174 & 55 & 33 & 60 \\
\hline $\begin{array}{l}\text { Woolner and McDonald } \\
\text { (1949) }\end{array}$ & & 147 & 100 & 67 \\
\hline $\begin{array}{l}\text { Jackson and others } \\
\text { (1951) }\end{array}$ & 270 & 100 & 61 & 61 \\
\hline This investigation & 966 & 395 & 240 & $60 \cdot 7$ \\
\hline
\end{tabular}

porated in the stain. As far as we are aware no previous series using this technique has been recorded. The selection of suitable portions of sputum for examination is of considerable importance and Gloyne (1936) has considered this in detail. The sputum should be carefully examined in a sterile Petri dish against a dark background. White streaks and bloodstained portions of the specimen are first choice for microscopy. In their absence puru'ent, mucopurulent, or simply mucoid elements are used in that order of preference. The selected parts of sputum are picked out with forceps and placed on a slide to which is added one drop of a $0.5 \%$ watery solution of methylene blue. The methylene blue is intimately mixed with the sputum and the slide very gently heated. A minute is sufficient time for adequate staining, and a large ( $1 \frac{1}{2}$ in. $\times \frac{7}{8}$ in.) covers ip is placed over the specimen and firmly pressed down to squash flat the larger particles. The film is examined with a $\frac{2}{3}$ objective and a $\times 10$ eyepiece and suspicious cellular areas identified with a $\frac{1}{6}$ objective.

It is best to use fresh specimens, but satisfactory preparations are obtainable after the sputum has been kept for 18 hours at room temperature or up to four days at $4^{\circ} \mathrm{C}$.
The advantages of this method are speed, simplicity, and constancy of staining. However, its impermanence due to the precipitation of the stain (the film can only be examined up to four hours after preparation) is an important disadvantage where films are required for later review.

\section{Appearances of Malignant and non-Malignant Cells}

Considerable experience in the variable cytological appearances in non-malignant cases is essential in order that familiarity with these cell types will render the recognition of malignant cells the more certain and avoid false positive results when atypical non-malignant cells occur.

We do not intend to describe the non-malignant cells in detail, as good descriptions have been given by Gloyne (1936), Woolner, and McDonald (1949) and by Farber and others (1950).

Squamous Cell Carcinoma. - Malignant squames are the cells most commonly encountered in the sputum in bronchogenic carcinoma. These cells show considerable variation in size, shape, and staining properties, and the nuclei show similar changes with prominent nucleoli. There is often a diminished nucleo-cytoplasmic ratio and small perinuclear globules, presumably of a degenerative nature, are not uncommonly present. These cells may show progressive peripheral keratinization which stains a pronounced greenish tint with methylene blue in contrast to the normal blue of all other parts of the film. We have often found this of considerable help, and where an occasional cell showing this staining characteristic is encountered, although otherwise not definitely malignant, a more prolonged search has often resulted in the finding of definite plaques of malignant cells.

Some cells will show abundant keratinizing cytop'asm, and the appearance of epithelial pearl formation in the presence of other atypical squamous cells is diagnostic of malignancy. Malignant squamous cells appear in the sputum as isolated cells or more commonly as separate cells distributed in streaks of material which may be casts of smaller bronchi or bronchioles, or malignant cells enmeshed in mucoid or mucopurulent exudate.

The variation in the histological appearance of squamous cell carcinoma of the bronchus from the well-differentiated type showing epithelial pearls on the one hand to the large-celled type with minimal squamous differentiation on the other explains the pleomorphic cytology in sputum of these growths. 
Small Cell Undifferentiated Carcinoma of "OAT" Cell TYPE.-This is encountered less frequently in the sputum than the squamous variety, and is not entirely due to the fact that it is a less common growth. When cells of this type are found in sputum, the diagnosis of primary bronchogenic carcinoma is virtually certain. The cells are smaller than the malignant squames. They appear as small clusters or as very characteristic dense clumps, and the individual cells show considerable hyperchromatism with virtually no visible cytoplasm. They must of course be distinguished from the small, less darkly stained groups of lymphocytes which do not show the clumping so typical of this growth.

Adenocarcinoma.-This is the least commonly encountered type. Massive vacuolation of malignant cells is suggestive of adenocarcinoma, but we do not believe that it is possible to distinguish cytologically these growths and we find that our report in these cases is usually "Carcinoma cells present." This is the experience of other workers (Woolner and McDonald, 1949, and Farber and others, 1950).

\section{Routine Cytological Examination and REPORTING}

Nearly all non-tuberculous patients and atypical tuberculous patients in whom there is suspicion of associated carcinoma have six morning specimens of sputum examined for malignant cells. In some clinically suspicious cases showing negative sputa up to 12 specimens may be examined. Three grades of reports are made: (1) Cells slightly suspicious of malignancy, (2) cells very suspicious of malignancy, (3) neoplastic cells present, either specified (e.g., squamous carcinoma cells) or unspecified (e.g., malignant cells present).

We have found that following bronchoscopy desquamated traumatized normal epithelial cells may mimic malignancy, and ideally no sputa are examined for malignant cells for 10 days after bronchoscopic examination. In some cases bronchoscopy is deferred until sufficient specimens have been collected.

The presence of a single cell possessing the morphological features of malignancy in a specimen of sputum is insufficient for a positive diagnosis. Numerous cells distributed singly or in clumps and showing these changes must be found before a positive diagnosis can be made. The experienced cytologist will find numerous sputa where only a few suspicious cells are seen and it is for these cases that the first method of report- ing is used and a request made for further specimens to be sent to the laboratory.

\section{Scope of the Present Survey}

Every patient with carcinoma of the bronchus admitted between January 1, 1950, and November 11,1952 , has been reviewed. There were 403 cases, and all but eight of these had sputum examined for malignant cells. A number, however, had less than the six examinations considered to be the minimum for a negative result.

Table II gives a general outline of the results.

TABLE II

OUTLINE OF RESULTS OF THIS REVIEW

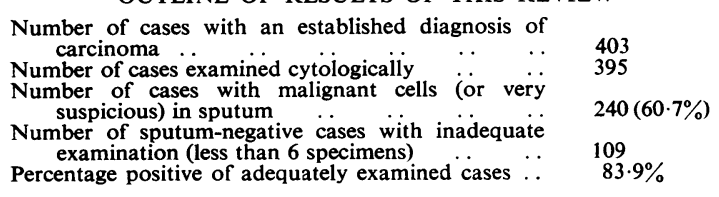

It is not suggested that an $83 \%$ positive result would have been obtained if all cases had had the minimum six examinations, but the figure would undoubtedly have been greater than $60 \%$, as 15 cases had one examination only and 55 cases three or fewer examinations. There were several reasons why the test was not completed, chief of which was the securing of definite or presumptive bronchoscopic, radiological, or other evidence of carcinoma.

It will be noted that the very suspicious group is taken together with the positive group. At the outset of the investigation we had a clinical impression that a report of "very suspicious" was a reliable guide and analysis showed this to be true. Non-carcinomatous cases in which such a report has been made have been placed in the falsepositive group. On the other hand, a report of "slightly suspicious" is faulty often enough to make it useful only as a suggestive link in the diagnostic chain.

An effort is made to distinguish the type of malignant cell found in the sputum and in 153 $(63.8 \%)$ the cells were of squamous type, the remainder being reported as "carcinoma cells present." The cell type of the growth was confirmed by microscopy in 290 (72\%) of the 403 cases, either by bronchial biopsy, operation, or necropsy. Where both biopsy and microscopic section of the specimen were obtained in the same case, the report sometimes differed because of the frequent occurrence of areas of differing histology in the same neoplasm. It was therefore to be expected that the sputum report would not always be confirmed as to the cell type by microscopy of the 
specimen, and in fact nine cases reported as having squamous cells were found to have a predominantly different pathology, six being mainly undifferentiated and three adenocarcinomatous.

Table III shows the final pathology in 290 cases with the cytologically positive and negative cases grouped separately.

TABLE III

FINAL PATHOLOGY IN 290 CASES

\begin{tabular}{|c|c|c|}
\hline $\begin{array}{c}\text { Predominant Histological } \\
\text { Cell Type }\end{array}$ & $\begin{array}{l}\text { Cytology } \\
\text { Positive }\end{array}$ & $\begin{array}{l}\text { Cytology } \\
\text { Negative }\end{array}$ \\
\hline $\begin{array}{l}\text { Squamous } \ldots \\
\text { Undifferentiated or anaplastic } \\
\text { Adenocarcinomatous }\end{array}$ & $\begin{array}{l}120(67 \%) \\
47(26 \cdot 3 \%) \\
12(6 \cdot 7 \%)\end{array}$ & $\begin{array}{l}38(34 \cdot 2 \%) \\
60(54 \cdot 1 \%) \\
13(11 \cdot 7 \%)\end{array}$ \\
\hline Total & $179(100 \%)$ & $111(100 \%)$ \\
\hline
\end{tabular}

There is a striking contrast in the relative incidence of the different types in the positive and negative groups. It is evident that malignant cells are much more likely to be found in growths of squamous type than in the undifferentiated or adenocarcinomatous types.

There were 227 (56.3\%) histologically unconfirmed cases, apart from operation or necropsy. While, on clinical, radiological, and bronchoscopic evidence the diagnosis in a large proportion of these cases was in little doubt, it is clearly an unsatisfactory state of affairs. Of these 227 cases, $139(61.2 \%)$ had malignant or very suspicious cells in the sputum. The figure below shows this in graphic form. The undiagnosed sector is reduced from more than one half to less than one-fifth by sputum examination.

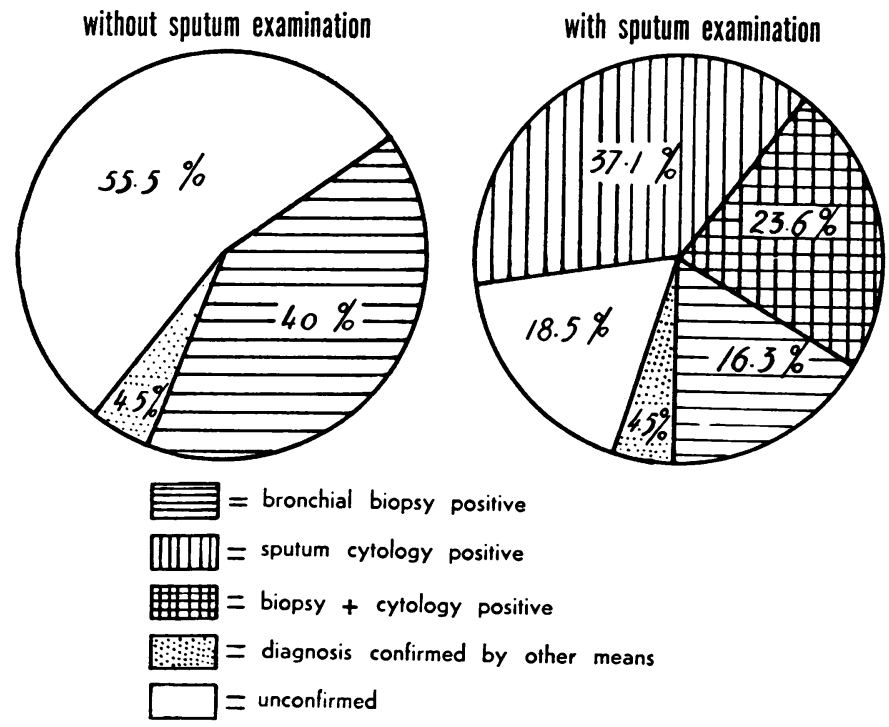

Table IV shows the relationship between cytology and biopsy diagnosis.

TABLE IV

RELATIONSHIP BETWEEN SPUTUM CYTOLOGY AND BIOPSY DIAGNOSIS

\begin{tabular}{|c|c|c|}
\hline & $\begin{array}{c}\text { Cytology } \\
\text { Positive }\end{array}$ & $\begin{array}{l}\text { Cytology } \\
\text { Negative }\end{array}$ \\
\hline $\begin{array}{ll}\text { Number of cases } & \ldots \\
\text { Number bronchoscoped } & \ldots \\
\text { Bronchial biopsy positive } & \ldots \\
\begin{array}{c}\text { Histologically diagnosed } \\
\text { other means }\end{array} & \ldots\end{array}$ & $\begin{array}{c}240(100 \%) \\
231(39 \cdot 2 \%) \\
94(39 \%) \\
7(2 \cdot 9 \%)\end{array}$ & $\begin{array}{c}155(100 \%) \\
148((41 \cdot 3 \%) \\
64(7 \cdot 1 \%) \\
11(7.0\end{array}$ \\
\hline $\begin{array}{l}\text { Total number histologically } \\
\text { diagnosed apart from spu- } \\
\text { tum examinations ... }\end{array}$ & $101(42 \cdot 1 \%)$ & $75(48.4 \%)$ \\
\hline
\end{tabular}

It should be noted that the proportion of growths from which a bronchial biopsy could be taken is, if anything, rather smaller in the cytologically positive than in the negative group. The position of the growth in the lung, whether peripheral or central, does not appear to influence the chance of finding malignant cells in the sputum.

The extent of surgery in the series is shown in Table V.

It will be seen that of those cases that came to resection, $64(39.6 \%)$ cases negative at biopsy had malignant cells in the sputum. One hundred and one cases $(62.7 \%)$ of the total resection group were sputum positive, and this figure corresponds closely with the percentage for the total series, showing that malignant cells are as likely to be found in the sputa from operable as from advanced cases.

To further this point, the well-defined group of round peripheral tumours was selected. Table VI shows an analysis of these cases.

It is particularly gratifying that this small but diagnostically baffling group of tumours shows a percentage of positive results similar to the general group. It may appear surprising that this is so, but it can probably be fully accounted for by the fact that carcinoma of the lung is almost invariably of bronchial origin.

\section{Clinical Discussion}

It is outside the scope of this communication to discuss the differential diagnosis of carcinoma of the lung, and it is now well recognized that almost any condition of the lungs may be simulated by malignant disease. It may not be out of place, however, to emphasize that exploratory thoracotomy does not always provide the correct answer. The sur- 
TABLE V

SPUTUM AND BRONCHIAL BIOPSY FINDINGS IN SURGICALLY TREATED CASES

\begin{tabular}{|c|c|c|c|c|c|}
\hline & & $\begin{array}{c}\text { Bronchial } \\
\text { Biopsy } \\
\text { Positive }\end{array}$ & $\begin{array}{l}\text { Cytology } \\
\text { Positive }\end{array}$ & \begin{tabular}{|} 
Confirmed \\
by Sputum \\
(Bronchial \\
Biopsy \\
Negative)
\end{tabular} & Total \\
\hline \multirow{3}{*}{$\begin{array}{c}\text { Resec- } \\
\text { tions }\end{array}$} & Pneumonectomy & $\begin{array}{c}51 \\
(45 \cdot 1 \%)\end{array}$ & $\begin{array}{c}82 \\
(72 \cdot 6 \%)\end{array}$ & $\begin{array}{c}48 \\
(42 \cdot 5 \%)\end{array}$ & $\begin{array}{c}113 \\
(100 \%)\end{array}$ \\
\hline & $\begin{array}{l}\text { Limited resec- } \\
\text { tion (lobar or } \\
\text { segmental) }\end{array}$ & $(12.5 \%)$ & $\begin{array}{c}19 \\
(39 \cdot 6 \%)\end{array}$ & $\begin{array}{c}16 \\
(33 \cdot 3 \%)\end{array}$ & $\begin{array}{c}48 \\
(100 \%)\end{array}$ \\
\hline & Total resections & $\begin{array}{c}57 \\
(35.4 \%)\end{array}$ & $\begin{array}{c}101 \\
(62 \cdot 7 \%)\end{array}$ & $\begin{array}{c}64 \\
(39 \cdot 8 \%)\end{array}$ & $\begin{array}{c}161 \\
(100 \%)\end{array}$ \\
\hline \multicolumn{2}{|c|}{ Thoracotomy only } & $\begin{array}{c}31 \\
(42 \cdot 5 \%)\end{array}$ & $\begin{array}{c}49 \\
(67 \cdot 1 \%)\end{array}$ & $\begin{array}{c}29 \\
(39 \cdot 7 \%)\end{array}$ & $\begin{array}{c}73 \\
(100 \%)\end{array}$ \\
\hline
\end{tabular}

TABLE VI

SPUTUM CYTOLOGY IN 42 ROUND PERIPHERAL TUMOURS

\begin{tabular}{ll|c|c|c}
\hline & $\begin{array}{c}\text { Cytology } \\
\text { Positive }\end{array}$ & $\begin{array}{c}\text { Cytology } \\
\text { Negative }\end{array}$ & Total \\
\hline Round peripheral tumours & $\cdots$ & $\begin{array}{c}27 \\
(64 \cdot 3 \%)\end{array}$ & $\begin{array}{c}15 \\
(35 \cdot 7 \%)\end{array}$ & $\begin{array}{c}42 \\
(100 \%)\end{array}$ \\
\hline
\end{tabular}

geon at thoracotomy of an undiagnosed pulmonary mass occasionally finds himself faced with an insoluble dilemma. He can feel a firm mass in the lung which could equally well be a carcinoma, lung abscess, tuberculous focus, or benign tumour. A limited resection may be inadequate for a carcinoma, while a pneumonectomy for a benign process should be avoided at all costs. Any investigation which helps to resolve this problem is clearly worth while.

Illustrative Cases.-The following cases illustrate this dilemma.

Case 1.-A woman aged 35 showed an opacity in the right lower lobe on radiography during investigation of chronic laryngitis. She had no symptoms referable to the chest. Cells very suspicious of neoplasm were found in the sputum. At thoracotomy a soft mass was felt in the apex of the right lower lobe. The diagnosis was in doubt and a segmental resection was contemplated. However, in view of the sputum report a lobectomy was performed. Histological examination revealed an adenocarcinoma.

Case 2.-A woman aged 40 had a vulvectomy for squamous carcinoma two years before admission for investigation of a small haemoptysis. A radiograph showed a round opacity in the anterior segment of the left upper lobe. Cells very suspicious of neoplasm were found in the sputum. At thoracotomy the lesion was very suggestive of a tuberculous focus, and it was incised to determine its nature. There was a ragged-walled cavity indistinguishable from a tuberculous lesion, and therefore, despite the sputum report, a segmental resection was performed. Microscopy showed a squamous carcinoma.

These two cases illustrate the difficulty sometimes experienced at exploratory thoracotomy.

Case 3.--A man of 50 with a productive cough for many years and haemoptysis intermittently for nine months was found on radiography to have bilateral apical mottling, more marked on the left side. A diagnosis of pulmonary tuberculosis was made, despite the repeatedly negative sputum. Tomograms showed cavitation at the left apex. Bronchoscopy showed no definite evidence of neoplasm, but he was found to have squamous carcinoma cells in the sputum. At thoracotomy a carcinoma was found in the left upper lobe, but mediastinal infiltration with glands made the growth inoperable.

Case 4.-A man of 44 had a right thoracoplasty for pulmonary tuberculosis, following which he developed a round opacity in the left lower apical segment. This was considered to be a tuberculoma, but examination of the sputum revealed cells very suspicious of neoplasm. A limited resection only was possible, and microscopy showed an undifferentiated carcinoma.

These two cases show the not infrequent difficulty in differentiating carcinoma from pulmonary tuberculosis.

\section{False Positives}

The significance to be attached to the cytological report of malignant cells in sputum must vary inversely with the number of false positives rendered by the observer.

Table VII shows the number of false positives reported by various authors expressed as a percentage of the cytologically positive bronchogenic carcinoma in each series. The finally established diagnosis in these cases is also given.

It is possible that two types of non-neoplastic cells in the sputum may result in these serious errors. Wandall believes that atypical macrophages resulted in his six mistakes, and Kjœr states that "atypical macrophages and proliferating alveolar endothelia appear to play an essential role as false tumour cells." Most other writers, however, have found that analysis of their false positive cases showed that metaplastic squamous bronchial epithelium was often present and could closely simulate a squamous carcinoma when exfoliated in the sputum. As Haythorn (1949) says, "desquamated epithelium from metaplastic areas may show prickles or cornification and resemble squamous cancer cells closely."

There were six false positive cases reported in the present series out of 563 non-malignant cases examined, and this represents $2.5 \%$ of the correct 
TABLE VII

FALSE POSITIVE RESULTS RECORDED BY PREVIOUS AUTHORS AND THOSE DURING THE PRESENT INVESTIGATION

\begin{tabular}{|c|c|c|c|c|}
\hline Author & \begin{tabular}{|c|} 
No. of \\
Bronchogenic \\
Carcinomata \\
in Series \\
with Positive \\
Sputum
\end{tabular} & $\begin{array}{c}\text { No. } \\
\text { of } \\
\text { False } \\
\text { Posi- } \\
\text { tive } \\
\text { Sputa }\end{array}$ & $\%$ & $\begin{array}{l}\text { Actual Diagnoses } \\
\text { in False } \\
\text { Positive Cases }\end{array}$ \\
\hline $\begin{array}{l}\text { Barrett } \\
(1938)\end{array}$ & 110 & 2 & 1.8 & Inflammatory (2) \\
\hline $\begin{array}{r}\text { Wandall } \\
(1944)\end{array}$ & 100 & 6 & 6.0 & $\begin{array}{l}\text { Pulmonary tuberculosis (3) } \\
\text { Chronic pneumonias (3) }\end{array}$ \\
\hline $\begin{array}{l}\text { Liebow and } \\
\text { others } \\
(1948)\end{array}$ & 49 & 3 & $6 \cdot 1$ & $\begin{array}{l}\text { Cylindrical bronchiectasis } \\
(2) \\
\text { Bronchiectasis (1) }\end{array}$ \\
\hline $\begin{array}{l}\text { McKay and } \\
\text { others } \\
(1948)\end{array}$ & 54 & 3 & $5 \cdot 5$ & $\begin{array}{l}\text { Bronchial polyp with meta- } \\
\text { plasia (1) } \\
\text { Not stated (1) } \\
\text { Pulmonary tuberculosis (1) }\end{array}$ \\
\hline $\begin{array}{l}\text { Kjœr and } \\
\text { others } \\
\text { (1949) }\end{array}$ & 112 & 14 & $12 \cdot 5$ & $\begin{array}{l}\text { Abscess (3) } \\
\text { Asthma (1) } \\
\text { Bronchiectasis (1) } \\
\text { Bronchostenosis (5) } \\
\text { Empyema (1) } \\
\text { Interstitial pneumonia (1) } \\
\text { Pleurisy (1) } \\
\text { Pulmonary tuberculosis (1) }\end{array}$ \\
\hline $\begin{array}{l}\text { Watson and } \\
\text { others } \\
\text { (1949) }\end{array}$ & 236 & None & & $\begin{array}{l}\text { He states that "bronchiec- } \\
\text { tasis has given false } \\
\text { positives previously" }\end{array}$ \\
\hline $\begin{array}{l}\text { Woolner } \\
\text { and } \\
\text { McDonald } \\
\text { (1949) }\end{array}$ & 150 & 3 & $2 \cdot 0$ & $\begin{array}{l}\text { Bronchiectasis (1) } \\
\text { Infarction with organizing } \\
\text { pneumonia (1) } \\
\text { Pulmonary tuberculosis (1) }\end{array}$ \\
\hline $\begin{array}{l}\text { Clerf and } \\
\text { Herbut } \\
(1950)\end{array}$ & 253 & 1 & 0.3 & Pulmonary abscess \\
\hline $\begin{array}{l}\text { Farber and } \\
\text { others } \\
(1950)\end{array}$ & 163 & 2 & $1 \cdot 2$ & $\begin{array}{l}\text { Pulmonary abscess (1) } \\
\text { Squamous metaplasia (2) }\end{array}$ \\
\hline $\begin{array}{l}\text { Perrin and } \\
\text { Littlejohn } \\
(1950)\end{array}$ & 33 & 2 & 6.0 & $\begin{array}{l}\text { Disseminated lupus (1) } \\
\text { Tuberculosis (1) }\end{array}$ \\
\hline $\begin{array}{l}\text { Jackson } \\
\text { and } \\
\text { others } \\
(1951)\end{array}$ & 61 & 4 & $6 \cdot 5$ & $\begin{array}{l}\text { Lipoid pneumonia and } \\
\text { bronchiectasis (1) } \\
\text { Pulmonary tuberculosis (2) } \\
\text { Undiagnosed after thora- } \\
\text { cotomy (1) }\end{array}$ \\
\hline $\begin{array}{c}\text { This inves- } \\
\text { tigation }\end{array}$ & 240 & 6 & $2 \cdot 5$ & $\begin{array}{l}\text { Chronic lung abscess (1) } \\
\text { Goitre (1) } \\
\text { Haemoptysis. No final } \\
\text { diagnosis (1) } \\
\text { Pulmonary tuberculosis (3) }\end{array}$ \\
\hline
\end{tabular}

positive reports. One of these came to necropsy and another had a pneumonectomy. In both cases considerable bronchial metaplasia was associated with chronic pulmonary tuberculosis. A third case of pulmonary tuberculosis was reported as very suspicious of malignancy four days after bronchoscopy and illustrates the danger of accepting positive results within 10 days of this procedure. The fourth was a case of chronic abscess of the right upper lobe treated by lobectomy. Histology showed that the cavity was partly lined by squamous epithelium. The fifth case was a woman of 63 with repeated haemoptysis of undetermined origin in whom exhaustive investigation, including bronchoscopy and bronchography, revealed no pulmonary abnormality. (This patient is still under observation.) The sixth case was one of simple goitre with no clinical or radiological evidence of pulmonary disease. The last two are perplexing because there appears to be no adequate explanation for these errors.

Apart from the above false-positive reports there were three cases of squamous carcinoma of the oesophagus in which squamous cells were reported in the sputum. These are not considered to be false-positive results but it should be borne in mind that where malignant cells are found in the absence of a demonstrable pulmonary lesion the possibility of a growth elsewhere in the respiratory or upper alimentary tract must be considered. Malignant cells have been found in carcinoma of the larynx and trachea (Woolner and McDonald, 1949) and these writers also report cells from carcinoma of the oesophagus.

The crux of the problem is whether the trained cytologist can avoid these errors. We believe that errors in the region of $2 \%$ are inevitable in sputum cytology because hyperplastic metaplastic bronchial epithelium can, even histologically, closely resemble squamous carcinoma in situ and occasional mistakes in such cases represent an inherent disadvantage of the method.

\section{SUMMARY}

A series of bronchogenic carcinoma in which the sputum was examined is presented. Of 395 cases of carcinoma of the lung $60.7 \%$ were sputum positive. There were six false positives $(2.5 \%)$ in 563 non-malignant cases examined. A wet-filmmethylene-blue staining method was used throughout, and this is the first reported series using this technique. The most commonly encountered malignant cells in sputum are of squamous type. The bronchial biopsy was positive in $39.2 \%$ of the cytologically positive group and in $41.3 \%$ of the cytology negative group and it is concluded from this that the position of the growth in the lung does not influence the chance of finding malignant cells in sputum. One hundred and one $(62.7 \%)$ of 161 resection cases were sputum positive, showing that malignant cells are as likely to be found in operable as in advanced cases. Four cases are recorded in the clinical discussion to illustrate the practical value of this investigation. 
We should like to thank Dr. K. F. W. Hinson for his advice in the preparation of this paper, and the consultant staff at the London Chest Hospital for permission to use their cases. We are grateful for the help given to us by Miss E. Taylor and Miss W. Harris of the records department.

\section{REFERENCES}

Bamforth, J. (1946). Thorax, 1, 118.

Barrett, N. R. (1938). J. thorac. Surg., 8, 169.

Beale, L. S. (1860). Arch. Med., Lond., 2 , 44.

Bezançon, F., and de Jong, S. I. (1912).' Traité de l'examen des crachats, p. 282. Masson, Paris.

Clerf, L. H., and Herbut, P. A. (1950). Amer. Rev. Tuberc., 61, 60.

Dudgeon, L. S. (1936). St. Thom. Hosp. Rep., Second series, 1, 51.

- and Barrett, N. R. (1934). Brit. J. Surg., 22, 4.

- and Patrick, C. V. (1927). Ibid., 15, 250 .

and Wrigley, C. H. (1935). J. Laryng., 50, 752

Farber, S. M., Rosenthal, M., Alston, E. F., Benioff, M. A., and McGrath, A. K. (1950). Cytologic Diagnosis of Lung Cancer. Springfield, Illinois.
Gloyne, S. R. (1936). Tubercle, Lond., 18, 292.

Gowar, F. J. S. (1943). Brit. J. Surg., 30, 193.

Hampeln, P. (1887). St. Petersburger med. Wschr., n.s. 4 (O.S. 12),

Haythorn, S. R. (1949). Amer. J. Path., 25, 819.

Jackson, E., Bertoli, F., and Ackerman, L. V. (1951). J. thorac. Surg., 21, 7.

Kjœr, T., Dreyer, V., and Hansen, J. L. (1949). Acta med. scand., Suppl. 234, p. 177.

Liebow, A. A., Lindskog, G. E., and Bloomer, W. E. (1948). Cancer,

McKay, D. G., Ware, P. F., Atwood, D. A., and Harken, D. E. (1948). Ibid., 1, 208.

Papanicolaou, G. N.' (1942). Science, 95, 438.

and Cromwell, H. A. (1949) Dis. Chest, 15, 412.

Perrin, J., and Littlejohn, G. T. (1950). J. clin. Path., 3, 40.

Schuster, N. H. (1947). Recent Advances in Clinical Pathology, p. 316. Edited by S. C. Dyke. Churchill, London.

Walshe, W. H. (1843). The Physical Diagnosis of Diseases of the

Lungs. London.
Wandall, H. H. (1944). Acta chir. scand., Suppl. 93.

Watson, W. L., Cromwell, H., Craver, L., and Papanicolaou, G. N. (1949). J., thorac. Surg., 18, 113.

Woolner, L. B., and McDonald, J. R. (1949). Surg. Gynec. Obstet., 88, 273

(1950). Ann. intern. Med., 33, 1164. 